\title{
Synonymy in English and Bulgarian Military Terminology (a contrastive study)
}

\author{
Valentina Georgieva \\ G.S. Rakovsky Defence Academy, Sofia
}

\section{Some Theoretical Considerations on Synonymy}

This paper discusses the existence of synonymy in English and Bulgarian military peacekeeping terminology. Although there is a general requirement that there should be no synonyms to terms because "terms are the linguistic representation of concepts and [...] the prescriptive attitude of the past associated one concept with only one term" (Sager 1990:57-58), in scientific and specialized (military in particular) texts we often find lexical units (terms) which seem to be semantically very close or identical.

The traditional definition of synonymy describes this linguistic phenomenon as a kind of semantic relation between two or more words (or phrases) with the same meaning. Webster's new dictionary of synonyms (1984:24) provides the following definition: “A synonym, in this dictionary, will always mean one of two or more words in the English language which have the same or very nearly the same essential meaning. [...] Synonyms, therefore, are only such words as may be defined wholly, or almost wholly, in the same terms. Usually they are distinguished from one another by an added implication or connotation, or they may differ in their idiomatic use or in their application".

Many linguists deny the existence of synonyms. Quine and Goodman, quoted by Edmonds and Hirst (Edmonds and Hirst 2002:107) argue that true synonymy is impossible, because it is impossible to define, and so, perhaps unintentionally, dismiss all other forms of synonymy. Edmonds and Hirst continue "Absolute synonymy, if it exists at all, is quite rare". Similarly, Ullmann (1957) says that "It is a truism that total synonymy is an extremely rare occurrence, a luxury that language can ill afford". Cruse (Cruse 1986:270) maintains that "natural languages abhor absolute synonyms just as nature abhors a vacuum" because the meanings of words are constantly changing. More formally, Clark (1986:171-188) employs her principle of contrast that "every two forms contrast in meaning" to show that language works to eliminate absolute synonyms. Either an absolute synonym would fall into disuse or it would take on a new nuance of meaning. At best, absolute synonymy is limited mostly to dialectal variation and technical terms (underwear $(\mathrm{AmE})$ : pants $(\mathrm{BrE})$; plesionym or a near-synonym), but even these words would change the style of an utterance when intersubstituted.

According to Lyons (Lyons 1981:148), the distinction may be drawn between a complete, absolute, and incomplete synonymy. He, like many other linguists, maintains that absolute synonyms defined by the property of having the same distribution and being completely synonymous in all their meanings and in all their contexts of occurrence are almost nonexistent. In his view "two expressions are full synonyms if the following conditions are met: all their meanings are identical; they are synonyms in all contexts; they are semantic equivalents in all aspects of their meaning" (Lyons 1995:61) and he claims that, though rarely, context restricted synonymy certainly exists. Other linguists tradition- 
ally distinguish absolute (full) synonyms from partial synonyms and believe that incomplete synonymy is not rare at all. In such a case the identity of one kind of meaning is most clearly recognizable, most commonly of the descriptive meaning (therefore it is referred to as descriptive synonymy), as in, for example, the set mother, mum, mummy, ma, mater. They are also called near-synonyms (or plesionyms), i.e. words that are close in meaning are almost synonyms, but not quite; very similar, but not identical, in meaning not fully intersubstitutable, but varying in their shades of denotation, connotation, implicature, emphasis, or register instead (Edmonds and Hirst 2002:107).

Based on this traditional distinction, the following classification diagram is suggested (Fig. 1) (Said):

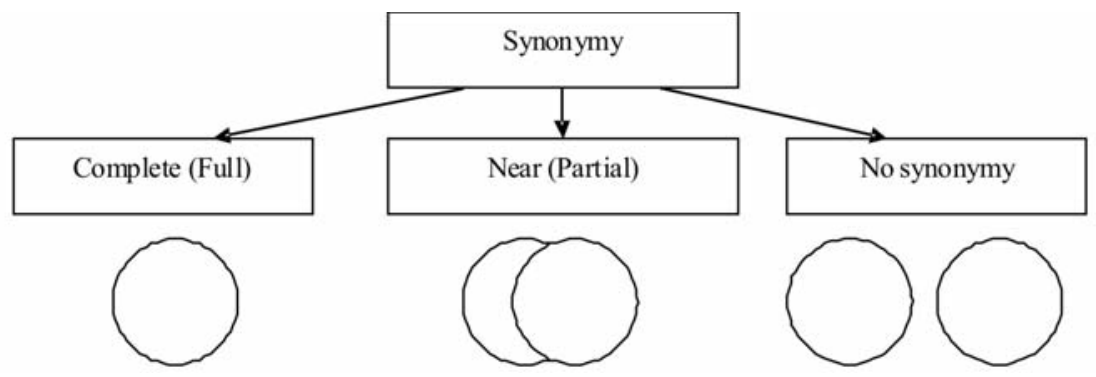

Fig. 1 Types of General Language Synonyms

Following the review of different types of synonymy in General English usage, we can discuss the situation in scientific terminology. According to J. Horecký, quoted by Kolaříková (2008) terminological synonyms are represented by such pairs as a loanword vs. domestic word; a one-word term vs. a two- (or more) word term; so called syntactic synonyms differing in the position of an attribute within a word-group (close or loose), or by such pairs that are neither stylistic nor lexical synonyms, but simply names for the same thing used simultaneously, so that the links between the older and newer literature of a given field are sustained. Emirzyan (1989:44) distinguishes between lexical and morphological synonyms in Bulgarian terminology. As a subtype of absolute (lexical) synonyms she mentions synonymous usage of "linguistic and non-linguistic elements", e.g. water $-\mathrm{H}_{2} \mathrm{O}$.

Several criteria may be used for differentiation of synonymous terms. One of them is substitutability, based on which, if two terms are substitutes for each other in all contexts of occurrence, they are said to be synonymous. In other words, if both terms satisfy the same definition, they are synonymous, because they name the same thing. Most linguists claim that "synonymy should not be tolerated in terminology, if the main purpose of terminology is facilitating scientific communication. [...] Whenever there is change in meaning caused by a change in the concept, or an additional connotation, we will consider terms to be different ones" (Popova 2012:591).

Danilenko (1977:73-74) explains the reason for the existence of synonymous terms as follows: "synonyms refer to the same concept and object, they do not refer to differ- 
ent characteristics". She also explains that lexical variants were coined at the beginning stage of development of a given scientific sublanguage in three main ways: 1) when there were few borrowings from different languages for the same concept; 2) when there was a word in the language coexisting with the borrowing; and 3) when a word was coined in a language simultaneously with the borrowing. This statement can be supported with the following examples from Bulgarian military terminology:

1) synonymous rows: миночистач - миночистачен кораб - тралчик - траличик - миннотрален кораб;

2) borrowing - domestic word: пилот - летещ;

3) borrowing - neologism: есминец - разрушител.

Molhova (1976:51) adds an interesting example: "In the history of a language there are periods abounding in synonyms for certain notions which fall out of use at a later period. Thus in Anglo-Saxon literature there are about 30 synonyms for the notion of warrior and almost the same number of words for the notion sea. The majority of these are completely obsolete in Modern English". Furthermore, Rossouw (1998) points out some important reasons for the existence of synonyms, or variants in military terminology where "new types of activity demanded description and nomenclature, the various role players each produced their own personal variations of the existing military terminology, rather than working towards a commonly acceptable solution to the problem. In the process, no clear semantic distinction has been made between the diplomatic/political and the military dimensions of international peace initiatives". In result, many synonymic terms have been coined for a given concept. This process is still continuing and leads to the absence of unification of military terms among native English military speakers, not to mention the whole international military community who use English as the main means for communication during international operations and initiatives.

In the last decade several attempts for unification and standardization of English military terminology have been made:

NATO Glossary of Terms and Definitions (English and French) (2013), where the terms are in the two official languages of NATO with the purpose "to standardize terminology used throughout NATO, thereby promoting mutual understanding" (further 'NATO' when referred to);

US Department of Defense Dictionary of Military and Associated Terms (2009), which "sets forth standard US military and associated terminology to encompass the joint activity of the Armed Forces of the United States in both US joint and allied joint operations" (further 'DOD' when referred to).

Despite the efforts for standardization, the NATO Glossary allows for the existence of synonyms, stating that "Each entry [...] contains first the preferred term in English followed by a slash and the equivalent term in French on the same line, followed on the lines below by any synonym and abbreviation, the definition, notes, examples, cross-references to related terms and figures, the source and the date on which the entry became NATO Agreed, i.e.: preferred term - admitted synonym - deprecated synonym obsolete synonym - abbreviation - Definition - Notes - Examples - Related terms source - date" (NATO:1-E-2). There is also an explanation: "Synonymy. Non-preferred 
terms are also listed as separate entries in alphabetical order, giving only a cross-reference to the preferred term" (NATO:1-E-2).

Another NATO document NATO Glossary of Standardization Terms and Definitions (English and French) (2011) gives the definitions of the types of synonyms:

preferred term is the most suitable for a given concept.

admitted term may be used for a given concept but is less suitable than the preferred term.

deprecated term is not suitable for a given concept.

obsolete term or the concept that it designates is no longer current.

These dictionaries are undoubtedly useful as a starting point for standardization of English military terminology; yet, the examples of interchangeably used military terms both in dictionaries and in authentic texts are numerous: e.g. naval mine (41 200 occurrences in the Internet) versus sea mine (35 000 occurrences); stationary weapon (2 370 occurrences) vs. static weapon (1 200 occurrences), etc.

Contemporary Bulgarian military terminology has been in use for a comparatively short period of time and has undergone the period of initial coining after 1878 when Bulgaria regained its independency. ${ }^{1}$ Significant changes followed after 1944 when Bulgaria became a member of the Warsaw Pact and received military equipment and armament from the Soviet Union. The new army structure and equipment which copied the Soviet model led to language transformations, characterized by borrowing Russian terms to name the new army organization, military ranks, units, armament, etc. Thus, numerous Russian terms were borrowed (маяк, бойна рубка, поиск, подводная лодка, рубеж); Bulgarian terms with Russian elements were coined (противолодочная оборона $\rightarrow$ противолодъчна отбрана); or Russian terms were calqued (охотник на подводнье лодки $\rightarrow$ ловец на подводници).

A new tendency started after 1990 with the political changes in Bulgaria which speeded up after Bulgaria joined NATO in 2004. English words and terms have entered all sublanguages, including military terminology. In addition to direct borrowings (бригада $\leftarrow$ brigade, брифинг $\leftarrow$ briefing, логистика $\leftarrow$ logistics, превенция на конфликти $\leftarrow$ conflict prevention, etc.) and lots of calques (мироопазване $\leftarrow$ реacekeeping, миротворчество $\leftarrow$ реасетаking, мироналагане $\leftarrow$ реасе enforcement, оценка на щетите oт битката $\leftarrow$ battle damage assessment; цивилно-военно сътрудничество $\leftarrow$ civilmilitary cooperation, команден канал $\leftarrow$ command channel) to justify the need for standardization among NATO members, lots of English abbreviations are also used (Главна квартира на обединените сили в Европа - ШЕЙП $\leftarrow$ Supreme Headquarters Allied Powers Europe - SHAPE, оперативен план - ОПЛАH $\leftarrow$ OPLAN).

Efforts for introducing the new English terms and finding their appropriate equivalent in Bulgarian military terminology have been made in the last decade: Английскобългарски военен речник. Всички термини на НАТО (2002) (further 'АБВР' when referred to), Интернационално командване. Наръчник за военни ръководители, офицери и сержанти (2003) (further 'ИК' when referred to), Английско-български терминологичен речник за мироопазващи операции, (2006) (further 'ТРМО' when referred to), Речник по национална сигурност и отбрана (2007) (further 'PHCO' 
when referred to), as well as the oldest Военен терминологичен речник (1979) (further 'BTP' when referred to).

\section{Classification of Military Terminology}

Several categories of synonyms can be observed in military terminology and we suggest the following more detailed classification of the synonymous terms, supported with examples from both English and Bulgarian peacekeeping terminology (See Fig. 2).

\section{Lexical Synonyms}

\subsection{Lexical absolute synonyms}

\subsubsection{Standard term - non-standard term}

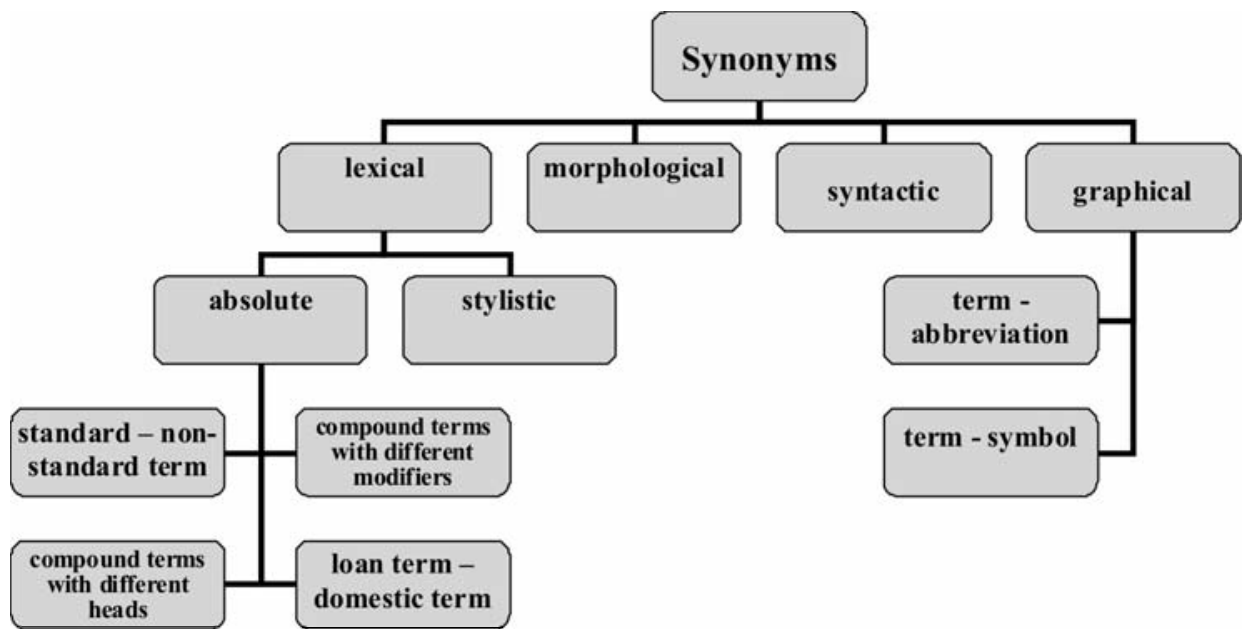

Fig. 2 Classification of synonymous terms

1.1.1.1. NATO Glossary permanently publishes new editions where synonymous terms are marked. In some examples of synonymous pairs the preferred form is longer and more precise, e.g.:

munitions / ammo (admitted) ammunition (admitted); exercise directing staff / directing staff (admitted) / DISTAFF; culminating point / culmination (admitted) (NATO).

Another group of terms includes the following examples:

attack position Preferred term: forming-up place

situational awareness / SA / battlespace awareness (obsolete) (NATO).

The possible reason for replacing the terms attack position and battlespace awareness is the willingness to substitute the more aggressively sounding terms with more neutral ones. Similar trend can be also noted in the following examples from $D O D$ :

make safe - One or more actions necessary to prevent or interrupt complete function of the system (traditionally synonymous with dearm, disarm and disable). 
law of war - That part of international law that regulates the conduct of armed hostilities. Also called the law of armed conflict.

1.1.1.2. Bulgarian terminology gives numerous examples for different translations of English terms that enter with international documents and NATO doctrines and are still in the process of standardization:

правила за бойно поведение (РНСО) - правила за предприемане на военни действия (АБВР) - правила на ангажимента (ТРМО) $<$ rules of engagement, степен на бойна готовност (АБВР) - положение, степен на готовност $(\mathrm{TPMO}) \leftarrow$ state of readiness, миротворчество (РНСО) - сключване на примирие (АБВР) $\leftarrow$ peacemaking, постоянен оперативен ред (АБВР) - стандартна процедура на опериране $(\mathrm{TPMO}) \leftarrow$ standing operating procedures,

вмъкване, включване (ТРМО) - навлизане в зоната на операция (АБВР) $\leftarrow$ insertion,

интервенция, вмешателство, намеса (ТРМО) $\leftarrow$ intervention,

обстрелване (АБВР) - ангажимент: малки тактически конфликти, обикновено между противостоящчи маневриращчи сили (ТРМО) $<$ engagement: the second term is an example of wrong interpretation of the concept and misleading borrowing.

\subsubsection{Synonymous compound terms with different modifiers}

1.1.2.1. A very large group of absolute English synonyms comprises absolute compound terms-synonyms which differ in the premodifying adjective/noun/participle before the head noun.

In the NATO Glossary the preferred of the two synonymous terms is given first, e.g. multinational force - combined force; NATO commander - Allied commander; combat patrol - fighting patrol; combat information centre - action information centre; appreciation of the situation - estimate of the situation; clandestine operation - discreet operation; core planning team - central planning team; nuclear weapon - atomic weapon.

A variation of this group of synonyms is the example of different postmodifying adjectives, e.g.: gun empty - gun clear (NATO).

1.1.2.2. The following terms exemplify the same group in Bulgarian terminology:

локална война - малка война; мобилна отбрана - подвижна отбрана (BТP);

преден команден пункт - изнесен команден пункт: ВТР defines преден КП, but ИК gives synonymous terms, probably translating literary the English forward command post. Internet gives statistics of 3:4 in favour of the second term which means that probably it will be accepted in the future under the influence of the English term. Similar is the situation with предно/изнесено командване (ИК).

минни заграждения - минновзривни заграждения: BTP gives both terms, but specialized literature prefers the first one, e.g.: "Районите, в които могат да се очаква наличие на морски минни заграждения (М3-М), се различават по дълбочината, [...]" (Dimitrov 2002:86). The first term is shorter and more general but this does not change the meaning of the concept. 
Bulgarian example of the different postmodifying noun is коригиране на стрелбата - коригиране на огъня (ВТР).

\subsubsection{Synonymous compound terms with different heads}

1.1.3.1. There are absolute compound terms-synonyms, which have the same modifier (adjective, noun or participle), but a different head noun, e.g.: essential supply - essential cargo; emergency establishment - emergency complement; chemical warfare chemical operation; dead space - dead zone; delaying action - delaying operation.

1.1.3.2. Bulgarian terminology includes the following synonymous terms from the same group, e.g.: бойна поддръжка (АБВР) - бойна подкрепа (ТРМО); подкрепа от страната домакин (ТРМО) - помощ от страна/нация домакин (АБВР); водна преграда - водно препятствие (ВТР).

\subsubsection{Loan term - domestic term}

1.1.4.1. Although rare, there are synonymous terms in which a military specialist can find and use terms of English or French origin in NATO Glossary. The explanation of coexistence of terms is the fact that English and French are the official languages in NATO and the interference between the two languages is unavoidable, e.g.: attenuation 3 / tone down - attenuation 3 (French); blister agent / vesicant agent - agent vesicant (French).

1.1.4.2. Bulgarian terminology includes lots of terms of Russian and English origin which are used simultaneously with a Bulgarian domestic term or cases of two nondomestic terms to represent a given concept.

1.1.4.2.1. Bulgarian term - Russian term

подводница - подводна лодка $(\leftarrow$ подводная лодка): Official Bulgarian documents contain both terms, e.g. $n$ is the abbreviation for подводница, but дивизион подводни лодки $=$ днпл, противолодъчна авиация $=$ ПЛА.

ескадрен миноносец - есминец - разрушител: the term ескадрен миноносеи and its synonym есминец are borrowed from Russian together with this type of ships from the Soviet Union (Todorov 1981:133). BTP defines миноносеи as "a subtype of ескадрен миноносеи with smaller draft and speed. Nowadays it is not so used" which proves that the term has become obsolete. Current documents present ескадрен миноносеи as synonymous to разрушител. This new term is a calque of the English term destroyer.

търсене на мини - поиск на мини: both terms coexist in official documents with the domestic head търсене and the Russian equivalent поиск, e.g.: "ВМС участват в провеждане на разузнавателни поиски на мини и поиски на подводници [...]”; “Търсенето на мини във военно време се извършва в определени райони и фарватери [...]".

ракета примамка - ловушка (ВТР)

бойна кабина - бойна рубка: The term with the Russian term element рубка is preferred in BTP.

1.1.4.2.2. Bulgarian term - English term

водосамолет - хидросамолет - хидроплан: Despite the attempts to introduce the 
Bulgarian term-calque водосамолет, the English one хидроплан ( $\leftarrow$ hydroplane) is preferred. летец - пилот $(\leftarrow$ pilot): Both terms are accepted and have derivatives in Bulgarian.

атомно оръжие - ядрено оръжие - нуклеарно оръжие $(\leftarrow$ nисlear $)$ : The term ядрено оръжие is most widely used both in the Internet and in documents. Dictionaries also include compound terms with ядрен, e.g.: ядрен удар, ядрен огън, ядрена бойна глава, ядрени бойни средства, etc.

1.1.4.2.3. Simultaneous usage of non-domestic terms

The examples below represent synonymic pairs of terms which are widely accepted and well incorporated in Bulgarian terminology, although they are foreign to the Bulgarian language origin:

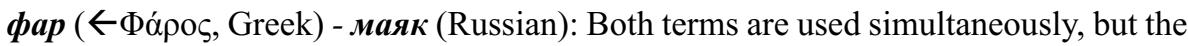
Russian one is more productive in derivatives, e.g.: радиомаяк - навигационен маяк радионавигационен маяк.

десантни сили ( $\leftarrow$ Russian) - амфибийни сили ( $\leftarrow$ amphibious): Bulgarian documents still prefer десантен and give амфибиен in brackets, but the situation might change under the influence of English terminology.

\subsection{Stylistic synonyms}

1.2.1. English military terminology is abundant with numerous examples of stylistic synonyms, jargon and slang words used extensively by military professionals to replace the official term. According to some linguists (Sudzilovski 1968) "English military terminology can be subdivided into 1) a. standardized vocabulary which includes terms from military documents and regulations, and b. informal vocabulary which is used in informal military speech and some types of military texts which are not official; 2) military jargon and slang which in most cases is synonymous to the corresponding standard terms. Both groups are characterized by the same peculiarities, i.e. special usage and meaning. In addition, words that belong to one of the groups, can be transferred from one group in the other, e.g. mess, pillbox, silo, $d u d$ which were jargon words are terms now".

Other examples of stylistic synonymic pairs include:

general - brass hat; private - GI; infantryman - doughboy; marine - devil dog, leatherneck, bootneck, Joeys, HM Jollies, shipboard soldier; submarine - sub, silent service, pigboat; destroyer - tin can; battleships - battlers, battle wagons; aircraft carrier - flat top; nuclear weapon - Doom's Day weapon.

1.2.2. Bulgarian military terminology contains only sporadic examples of slang words which are synonyms to official terms: отдаване на военна чест-козируване: the term is the first one, but informally the second one is also used.

\section{Morphological Synonyms}

This group is the one with the least number of synonyms in both terminologies. Most of the examples include terms with different suffixes, e.g.:

2.1. dispersion 6 (NATO) Preferred term: dispersal;

combination influence mine - combined influence mine $(*)^{2}$. 
2.2. зенитно прикритие: ВТP defines this term with the synonymous noun прикриване;

поразяване на иелта - поражение на ичелта: Here the Internet usage ratio is 378:6. Although BTP defines the differences between поразяване (на иелта) and поражение, present documents prefer поражение (на войските и силите).

It is possible that some of the following Bulgarian noun terms with the suffix -ция could be used simultaneously with their counterparts with the suffix - $\boldsymbol{\mu}$ e, but since they are borrowings of the term ending in the suffx -tion, it is a norm that they are formed with -ция: евакуация, дезактивация, дегазация, дезинформация, демилитаризация, демобилизаџия, демонстраџия, детонация, дислокаџия, диспозиџия, имитаџия, индикация, капитулация, еtс.

\section{Syntactic Synonyms}

3.1. English terminology provides lots of examples of this type of compound terms with a prepositional postmodification by an of-phrase which is synonymous to a complex term with surface structure $\mathrm{N}+\mathrm{N}$ : description of target - target description; chain of command - command channel (*). Similarly, Bulgarian terms for the latter English term show uncertainty Adj. $+\mathrm{N}$ or $\mathrm{N}+$ prep. $+($ Adj) $+\mathrm{N}$ : командна верига (ред), линия на подчинение, команден канал (ТРМО) - ред на подчинение (АБВР).

Other Bulgarian examples include:

$\operatorname{Adj}+\mathrm{N}=\mathrm{N}+$ Prep.+(Adj.)+N: противолодъчен кораб - кораб за противолодъчна отбрана, спомагателен кораб - кораб със спомагателно назначение, фронтова линия - линия на фронта, всесезонно оръжие - оръжие за всякакво време $(\leftarrow$ allweather weapon).

Several English two-component terms resulted in the following Bulgarian syntactic synonyms:

force protection $\rightarrow$ защчита на войските (АБВР) - защчита, охрана на собствените ВC - защитни, охранителни мерки (ТРМО),

peace enforcement $\rightarrow$ мироналагане, налагане на мира със сила (РНСО) налагане на мир (АБВР),

collateral damage $\rightarrow$ странични щети и загуби (ТРМО) - косвени щети (АБВР),

humanitarian aid $\rightarrow$ хуманитарна помощ - мерки за хуманитарна помощ, (TPMO),

3.2. Synonymous terms - result of shortening of the complex term when (one of) the modifier(s) is omitted, e.g.:

initial contact report Preferred term: contact report; humanitarian operation humanitarian relief operation (admitted); early warning - air defence early warning; gun carriage - carriage (NATO); dome / Preferred term: spray dome (*); date line Preferred term: international date line $(*)$.

3.3. Synonymous terms - result of blending:

danbuoy laying - danlaying

бойно снабдяване - боеснабдяване, бойни припаси - боеприпаси, боен комплект - боекомплект, газово убежище - газоубежище. 


\section{Graphical Synonyms}

According to Popova (2012: 602) "Graphical are the variants where at least one of the terms is an abbreviation". We can expand this definition adding that in military terminology one of the equivalent terms can be a symbol.

\subsection{Term-abbreviation}

Military language is characterized by extensive usage of abbreviations of the terms. Here is an example paragraph from the NATO document about Peace Support Operations AJP 3.4.1 (2001:52): "On the recommendations of the PMG, having considered advice from the Military Delegates Group, the Council will decide the mission and structure of the force. The Council appoints the Operation Commander and selects the Operation HQ, the FC and designates the Point of Contact (POC). If NATO assets and capabilities are used, the NAC, with the advice of the Military Committee, selects for proposal to the WEU Council the Operation Commander and the Operation HQ as well as, if foreseen, the FC and Force HQ".

In NATO Glossary of Standardization Terms And Definitions (2011:12) "only initialisms, acronyms, shortenings and clipped terms that are formed by truncating complex terms are considered as abbreviations and standardized".

4.1.1. Most of the abbreviations in English and Bulgarian terminology are initialisms, i.e. formed from the first letters of the words abbreviated, and pronounced letter by letter, e.g.:

$\boldsymbol{P K} \leftarrow$ peacekeeping, $\boldsymbol{P S O} \leftarrow$ peace support operation, $\boldsymbol{P S F} \leftarrow$ peace support force (NATO); $\boldsymbol{C} \leftarrow$ command center (DOD).

ОПМ $\leftarrow$ операции за поддържане на мира, ВМС $\leftarrow$ Военноморски сили, $\boldsymbol{\Gamma Щ}$ Генерален щзаб, ОП $\leftarrow$ оперативно планиране, ППУ $\leftarrow$ преден пункт за управление.

4.1.2. Another group are acronyms, i.e. abbreviations made up of the initial letters of the components of the full form of the designation or from syllables of the full form, pronounced as a word, e.g.:

NATO, SHAPE, STANAG (NATO), LOTS operations $\leftarrow$ logistics over-the-shore operations (DOD).

НАТО, Станаг, КИС $\leftarrow$ комуникационни и информаџионни системи, БИП бойно информаџионен пост, БОВ $\leftarrow$ бойни отровни вещеества.

4.1.3. A third group comprises clipped terms which are derived from first parts of compound terms, e.g.:

$\boldsymbol{P s y} \boldsymbol{O p} \leftarrow$ psychological operation, DAMCON $\leftarrow$ damage control, DISSUB personnel $\leftarrow$ distressed submarine personnel.

Bulgarian examples are new complex terms and their abbreviations formed after the English model: ОПЛАН $\leftarrow$ оперативен план, кОНОП $\leftarrow$ концеепия на операцията, ДесО $\leftarrow$ десантен отряд.

INTEL $\leftarrow$ intelligence and $\boldsymbol{C O M} \leftarrow$ commander and Bulgarian Ком $\leftarrow$ командир are examples of apocope which is the most frequent type of clipping in English when the final phoneme or syllable is dropped.

4.1.4. The fourth group of abbreviations includes shortenings made up of the first letter and possibly one or more other letters of a simple term, e.g.: 
alt. $\leftarrow$ altitude, lchr $\leftarrow$ launcher, $\boldsymbol{r g t} \leftarrow$ regiment.

Арс $\leftarrow$ арсенал, пр-к $\leftarrow$ противник, $\boldsymbol{\phi p} \leftarrow$ фрегата.

4.1.5. The next English group of synonymous terms comprises abbreviations in which there is a combination of letters and numbers, e.g.: $\boldsymbol{C} 2 \leftarrow$ command and control; $\boldsymbol{C} 2 \boldsymbol{S} \leftarrow$ command and control system; C4 $\leftarrow$ Command, Control, Communications and Computers; $\mathbf{C} 3 \mathbf{I} \leftarrow$ Command, Control, Communications and Intelligence.

Kocharyan (2007) defines numbers in this type of abbreviations as metasigns, i.e. "signs to substitute other signs with a different meaning from the general meaning".

4.1.6. The last group includes abbreviations in which the letters that substitute the compound term or part of it do not coincide with the first letters of the term: $\boldsymbol{C V}$ or $\boldsymbol{C V N}$ $\leftarrow$ aircraft carrier $\mathrm{CVN}$ is nuclear powered (DOD); decoy ship / Q-ship; K-KILL $\leftarrow$ complete kill (NATO).

What is typical for different types of graphical synonyms (abbreviations) is inconsistency in their spelling with capital or small letters, e.g.: battalion: $\boldsymbol{B n}-\boldsymbol{B N}-\boldsymbol{b n}$; European Command: EUCOM - EuCom - Eucom; casualty report: CasRep-CASREP.

If there is a slash in the abbreviation, it can be used to:

- mark the boundaries between parts of the compound terms, e.g.: $\boldsymbol{a} / \boldsymbol{c}$ - aircraft; $\boldsymbol{C} / \boldsymbol{A}$ - counterattack; $\boldsymbol{F} / \boldsymbol{C}$ - flight control; $\boldsymbol{M} / \boldsymbol{R}$ - morning report.

- to substitute a preposition or a conjunction, e.g.: $\boldsymbol{A} / \boldsymbol{G}$ - air-to-ground; $\boldsymbol{C} / \boldsymbol{S}$ - chief of staff; $\boldsymbol{c} / \mathbf{s}$ - cycles per second; $\mathbf{s} / \mathbf{c}$ - second-in-command. Sometimes there is additional information after the slash, e.g.: DCS/O Deputy Chief of Staff, Operations.

\subsection{Term - symbol}

NATO countries have agreed and accepted a system of symbols to represent various military facilities, units, weapons, etc. in order to use them on maps, so that all allies have the same understanding of what is depicted on maps and charts. This means that a study of a given term should be inseparable from a memorization of its symbol. Some examples of the symbolic representation of military terms are:

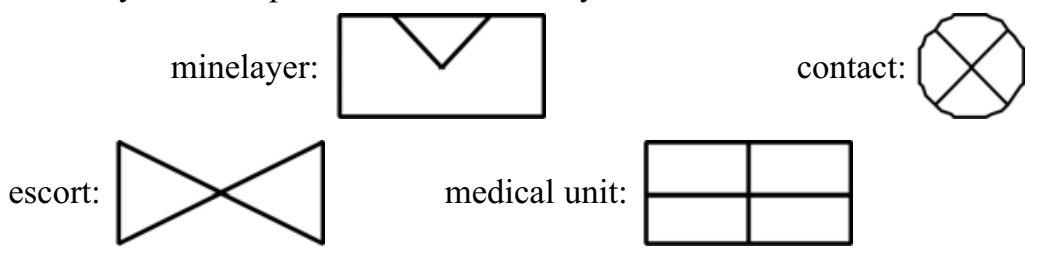

\section{Conclusions}

All of the above considerations and examples prove the existence of numerous synonyms in English and Bulgarian Military terminology (including terms related to peacekeeping) despite the attempts for their unification and standardization.

1. Most of the synonymous terms are complex terms and include synonyms in some of their parts (pre-modifiers or heads). From the four main groups of synonyms, lexical synonyms are the most widely observed and used in both terminologies. The main reason for their coexistence/interchangeability is the process of constant invent of new 
weapons and strategies, new organizational formations, as well as introduction of new military and political concepts and doctrines.

2. Morphological synonyms are less compared to other types of synonyms in both terminologies due to precise definition of the concept which avoids inconsistent usage of suffixes or prefixes.

3. The process of extensive usage of military abbreviations is especially significant and influential. Active usage of different types of abbreviations (initialisms, acronyms, shortenings and clipped terms) and standardized NATO symbols is the result of two main reasons: 1) English military writing traditions; and 2) the strive for terminological standardization and thus - facilitation of communication between NATO members during international exercises and operations through usage of NATO approved and accepted terms and non-verbal (symbolic) means.

4. The main difference between the contrasted terminologies is the existence of stylistic synonyms in English unlike Bulgarian military terminology which does not allow this.

5. Bulgarian terminology abounds in synonymous terms of domestic and English or Russian origin, while English terminology presents only a few examples of French borrowings.

6. English direct borrowings and calques enter rapidly into Bulgarian terminological systems, including military terminology.

7. The research proves the fact that Bulgarian military terminology is still in the process of active creation because there is hesitation and inconsistency in usage of synonymous or incorrectly borrowed/calqued terms even in official documents and dictionaries. This contrastive study proves Danilenko's statement (Danilenko 1977:74) that "synonymy is typical of initial stages of establishment of terminological systems when the process of uncontrolled (and conscious) selection of the most appropriate term is still under way and lots of alternative terms coexist. The establishment of a given terminological system is achieved through overcoming of synonymy".

\section{Notes:}

1. Bulgarian Armed Forces were officially declared in 1878. Bulgarian officers were trained in Bulgaria and in military academies in Russia, Italy, Austria-Hungary and France. $<$ http://bg.wikipedia.org/wiki/българска армия $>$

2. The symbol (*) shows that the terms are both in NATO Glossary and DOD Dictionary.

\section{References:}

1. Clark, E. (1992) Conventionality and Contrast: Pragmatic Principles with Lexical Consequences. // Frames, Fields, and Contrasts: New Essays in Semantic and Lexical Organization. Lawrence Erlbaum. 
2. Cruse, D. (1986) Lexical Semantics. Cambridge: CUP.

3. Danilenko, V. (1977) Russian Terminology. M.: Nauka.

4. Dimitrov, H. (2002) Morski mini $i$ borbata s tyah. Varna: MO, VVMU "N.I. Vaptsarov".

5. Edmonds, P., Hirst, G. (2002) Near Synonymy and Lexical Choice. // Computational Linguistics, Vol. 28, N2.

6. Emirzyan, A. (1989) Obshtoezikovi semantichni protsesi v terminologiyata (s ogled na stroitelnata terminologichna podsistema). // Bulgarski ezik, N 1.

7. Kocharyan, Y. (2007) Abreviatsiya $v$ angliskoy voennoy leksike. $<\mathrm{http}$ ://cheloveknauka.com/abbreviatsiya-v-angliyskoyvoennoyleksike\# ixzz2URLDWkm6>.

8. Kolaříková, Z. (2008) Synonymy in English Botanical Terminology. // SKASE Journal of Translation and Interpretation. Vol. 3 (1). <http://www.skase.sk/Volumes/ JTI03/pdf_doc/5.pdf $>$.

9. Lyons, J. (1981) Language and Linguistics. An introduction. Cambridge: CUP.

10. Lyons, J. (1995) Linguistic Semantics: An Introduction. Cambridge: CUP.

11. Molhova, J. (1976) Outlines of English Lexicology. Sofia: Naouka i izkustvo.

12. (2001) Peace Support Operations AJP 3.4.1. <http://www.osrh.hr/smvo/Library/ajp3.4.1.pdf>

13. Popova, M. (2012) Teoriya na terminologiyata. Veliko Trnovo: Znak'94.

14. Rossouw, B. (1998) South African National Defence Force. // African Security Review, Vol. 7 (1). (also online <www.iss.co.za/Pubs/ASR/7No1/Rossouw.html>).

15. Sager, J. (1990) A Practical Course in Terminology Processing. Amsterdam/Philadelphia: John Benjamins.

16. Said, M. (2007) Synonymy in Translation. // Translation Journal, Vol. 11, N 4.

17. Todorov, I. (1981) Bulgarskite korabi. Sofia: Technika.

18. Ullmann, S. (1957) The Principles of Semantics. Oxford: Basil Blackwell.

19. (2002) English-Bulgarian Military Dictionary. NATO Terms. Sofia: Trud. [АБBP]

20. (2006) English-Bulgarian Terminological Dictionary of Peacekeeping Operations. Sofia: Voenno izdatelstvo. [TPMO]

21. (1979) Military Terminological Dictionary. Sofia: Voenno izdatelstvo. [BTP]

22.(2013) NATO Glossary of Terms and Definitions (English and French). $<$ http://nsa.nato.int/nsa/zPublic/ap/aap6/AAP-6.pdf > [NATO]

23. (2011) NATO Glossary of Standardization Terms And Definitions (English and French). $<$ http://nsa.nato.int/nsa/zPublic/ap/AAP-42>.

24. (2007) Rechnik po natsionalna sigurnost i otbrana. Sofia: Voenna akademia "G.S. Rakovski". [PHCO]

25. Sudzilovski, G.; Borisov, V. (1968) English-Russian Military Dictionary. Moscow: Voennoe izdatelstvo. (also on-line http://www.zw-observer.narod.ru).

26. (1984) US Department of Defense Dictionary of Military and Associated Terms (as amended through 19 June 2009). < http://www.js.pentagon.mil/doctrine/jel/doddict/>. [DOD]

27. Webster's new dictionary of synonyms; a dictionary of discriminated synonyms with 
antonyms and analogous and contrasted words. Springfield, Mass., USA: MerriamWebster.

28. Yostman, P.; Aleksandrov, S. (2003) Internatsionalno komandvane. / Narachnik za voenni rakovoditeli, ofitseri i serzhanti. Sofia: Informa intelekt. [ИК]

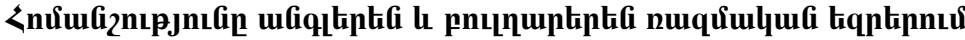 (huútiúumuluti nsunıúfiuuppnıpjnıf)}

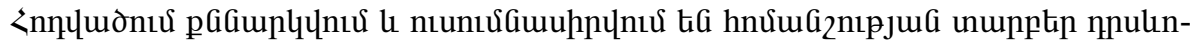

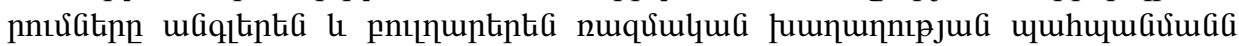
nıрпцud tiqnknnu:

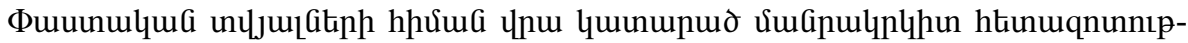

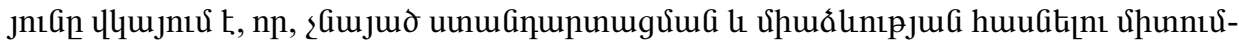

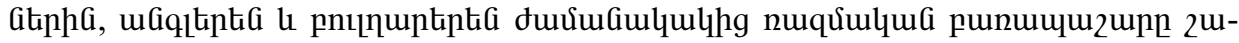

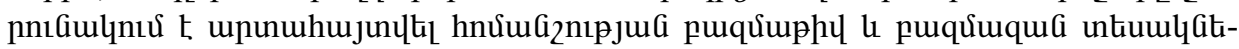
nny: 